\title{
Analysis of Information Systems Capabilities and Performance of Firms in Telecommunications Industry, Kenya
}

\author{
Bett, Alfred Kipyegon, PhD Candidate ${ }^{1}$, Dr. Johnmark Obura, PhD ${ }^{2}$, Dr. Moses Oginda, PhD ${ }^{3}$.
}

School of Business and Economics, Maseno University, Maseno, Kenya

\begin{abstract}
In the $21^{\text {st }}$ century where economies are driven majorly by knowledge and information-based service businesses, telecommunication industries are playing a critical economic role both regionally and globally. In Kenya, with a combined subscription rate of 37.8 million based on a 2016/17 Communication Authority of Kenya report of 2017, Safaricom Kenya Limited controls about $71.2 \%$ of the subscribers, Airtel Kenya Limited is second with $17.6 \%$ with Telkom Kenya coming third with $7.4 \%$. Finserve East Africa (Equitel) a new entrant in the market controls 3.8\% of subscribers. These figures points to the fact that only Safaricom seems to be the only firm performing well. This reality forms the basis of establishing whether their difference in performance is attributable to their information systems capabilities. The purpose of this study was to analyse the relationship IS capabilities and performance of firms in the telecommunications industry in Kenya. It was anchored on Resource-Based Theory and guided by a conceptual framework with the dependent variable being firm performance while independent variable was IS capabilities. Correlational and survey research designs were used. The population of the study was 408 staff comprising all executive, management and operational level managers from the business and IT sections in each firm. A sample of 202 staff was drawn through proportionate stratified random sampling method. Primary data was collected using structured questionnaire and an interview schedule. Reliability of the research instrument was tested against Cronbach's alpha coefficient where a reliability score of 0.814 was achieved while validity was gauged through research experts' opinions. Data was analysed using both descriptive and inferential statistics. The findings established that IS capabilities and firm performance have a weak relationship $(\mathrm{r}=0.409, \mathrm{p}<0.05)$ which means that whenever firms in industry invested on market based IS capabilities there was a small improvement on their performance and therefore firms should invest in the development of market based IS capabilities since they have significant influence on their performance. This study may be useful to industry players by gaining better understanding on various information system resources that they can utilize to improve and sustain their performance besides policy formulation. By advancing a model that depicts the relationship between information systems resources and firm performance, this study may make a significant contribution to theory building in the field of information systems.
\end{abstract}

Key Words: Information Systems, Capabilities, Performance, Firm, Competencies, Technology.

\section{INTRODUCTION}

Information systems capabilities refer to the ability that an organization assembles, integrates, and deploys its valued IS resources to build unique competencies (Teece, Pisano and Shuen 1997). Schreyogg and Kliesch-Eberl (2007) view capabilities as evidence of organisational learning.

In a global perspective, firms are focusing on becoming more competitive by launching competitive strategies that give them an edge over others, hence the emergence of IS capabilities and core competence as a central concept for competitive strategy. Makadok (2001) made a distinction between a firm's resources and its capabilities: a resource is an observable but not necessarily tangible asset that can be independently valued and traded, while a capability is unobservable and hence necessarily intangible cannot be independently valued and changes only as part of its entire unit.

Finney, Leug and Campbell (2008) offered an argument that places essential competencies as the principal means by which a firm can create and sustain a competitive advantage. In that research, Finney et al., (2008) marked core competencies as being made up of combinations of a company's resources and capabilities. Besides, these 
competencies are valued by the market and are also difficult for competitors to match. In essence, a company is able to differentiate itself from its competitors on the basis of core competencies and this is what enables it to out-perform its rivals.

Although IT as a valuable resource can improve firm performance, IT resources may not create sustained firm performance by themselves (Rai et $a l .$, 2006). The most recent understanding is that the effect of valuable resource goes through some other factors, major ones includes resource complementary and organizational capabilities. Resource complementary argues that the integration of different complementary resources can generate synergy that leads to better performance (Wade and Hulland, 2004; Melville et al., 2004; Karimi et al., 2007; Zhu et al., 2004). Organizational capabilities contend that IT resources can enhance critical organizational capabilities, which can boost firm performance (Bharadwaj, 2000; Bhatt and Grover, 2005; Rai et al., 2006; Brown et al., 1995).

A number of studies on IS/IT capabilities have been carried out for instance, Akinbola, Adeniyi, and Oluwatosin (2014) on IS capabilities in telecommunication service businesses in Nigeria, Bhatt and Grover (2005) on information technology capabilities and their role in competitive advantage, Oh and Kim (2013) on managerial capabilities of Information Technology and firm performance, Ainin et al., (2015) studied organization's performance, customer value and the functional capabilities of information systems, Antonia and Tomas (2008) carried out a study on the strategic value, resources and capabilities of the information systems area and their impact on organizational performance in the hotel sector and lastly Nyangi, et al., (2015) on organizational capabilities and performance of sugar manufacturing firms.

While a variety of capabilities in different industries have been identified in the empirical literature cited, the present study borrowed from Ravichandran and Lertwongsatien (2005) and Ravichandran and Rai (2000) frameworks that identified IS capabilities indicators as IS planning, IS development and IS support maturity. These capabilities can develop at various levels in the organisation such as at the departmental, divisional or organisational level to improve firm performance.

\section{A. Statement of the Problem}

In this day and age where markets are dynamic, firm performance is driven not by the physical resources but by intellectual and knowledge based resources and capabilities driven by information technologies. The challenge facing most firms is the ability to develop market based capabilities as the ground to establishing sustainable competitive advantage. It is when resources and capabilities are ingeniously managed, through a mixture of skills and knowledge that a firm can gain. In Kenya, firms in the telecommunications industry have portrayed mixed performance results with only Safaricom Kenya Limited sustaining its performance over the years. In the financial year which ended $31^{\text {st }}$ March 2017; the company announced its' service revenue of $85.5 \%$; while Airtel Kenya Limited announced its service revenue of $14.43 \%$ with Telkom Kenya and Equitel returning a $0.01 \%$ and $0.06 \%$ respectively. On Market share, Safaricom Kenya Limited controls $71.2 \%$ of the total subscription followed by Airtel Kenya with $17.6 \%$ with Telkom Kenya and Finserve East Africa (Equitel) controlling a market share of $7.4 \%$ and $3.8 \%$ respectively. With the belief that the performance of any company in any industry is affected directly by how they employ IS resources to come up with market based IS capabilities, this study sought to analyse the relationship between IS capabilities and performance of firms in the telecommunications industry in Kenya. The researcher endeavoured to establish whether there is a difference in the way firms ingeniously identify and develop their IS capabilities and whether the difference in performance can be accredited to that. Though a number of studies have attempted to establish link between IS resources, IS capabilities and firm performance, limited research has shown the interaction between IS capabilities on its own and firm performance.

The main aim of the study was to analyse the relationship between IS capabilities and performance of firms in the telecommunications industry in Kenya.

\section{B. Conceptual Framework}

The study model was guided by empirical analyses from previous models such as those of Ravichandran and Lertwongsatein (2005), Yashil (2009) and Mitra and Chaya (1996) that have attempted to integrate empirical research findings on the relationship between IS capabilities and firm performance as cited in the literature.

This study adopted the following conceptual framework shown in figure 1.1 derived from the objectives of the study. 


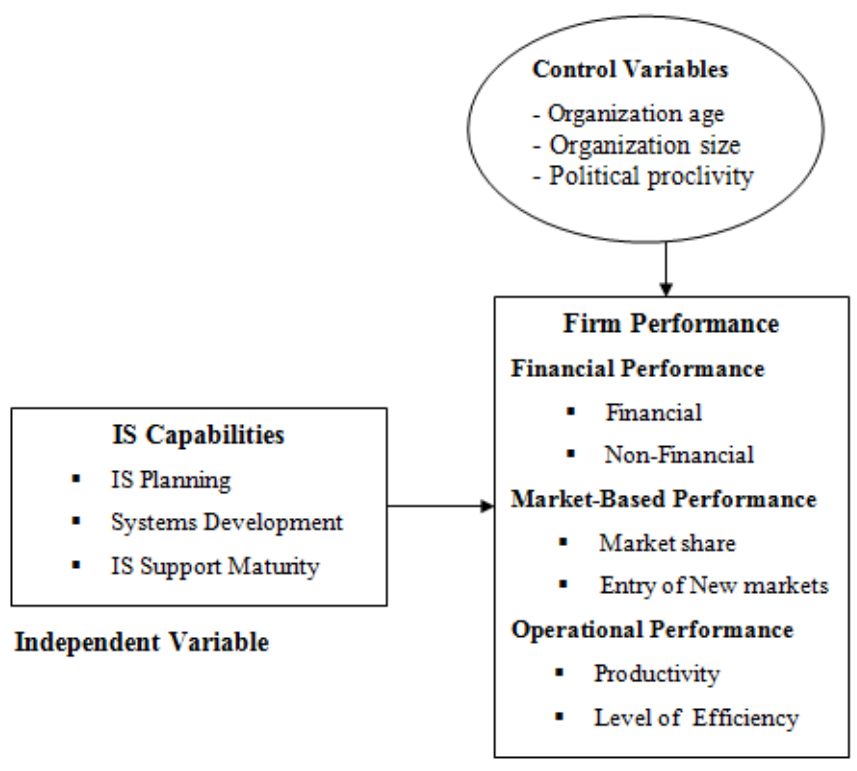

Figure 1.1: Conceptual Framework

Source: Adapted and modified from (Mitra and Chaya, 1996; Yashil, 2009; Ravichandara and Lertwongsatien, 2005).

Conceptual framework in figure1.1 above depicts the research framework being investigated in the study. The model describes the influencing mechanism of independent variable IS capabilities (i.e., IS planning, systems development and IS support maturity) on the dependent variable firm performance.

\section{Control Variables}

Control variables are used to account for factors other than the theoretical constructs of interest, which could explain variance in the dependent variable. In this study, organization size, organization age, and political proclivity were taken as control variables. Organization size mirrors past success and can influence current performance of an organization (Aldrich and Auster, 1986).

Organization age is perceived as a sign of external legitimacy of the existence of a firm, its staying power and the pervasiveness of internal routines (Fichman and Kemerer, 1993; Kalyanaram, and Wittink, 1994) all of which can have an impact on performance. On the other hand, young firms can be subject to the disadvantage of newness, which can muddle their performance (Aldrich and Auster, 1986; Hannan and Freeman, 1984; Stinchcomb, 1965). Political proclivity was introduced in the study as a new control variable which according to the researcher has a potential effect on firm performance, this is because of the presumption especially in Kenya that politics and power play influences the success of some of the industry players under study.

\section{Resource Based Theory}

How a firm controls its key resources will determine its performance (Wernerfelt, 1984). The focus of the Resource Based Theory (RBT) is on attributes of resources and capabilities gained from them to clarify a firm's heterogeneity, performance and sustainability. Further, resources are substances of approach in that gaining dominance in an aggressive marketplace is dependent on firm capability to recognize, build up, position and safeguard meticulously resources that differentiate it from its competitors (Mahoney and Pandian, 1992). Barney, Wright and Ketchen (2001) noted that every firm owns a diverse outline of tangible and intangible resources. Barney (2007) is one of the late contributors of RBT who studied and established the existence of key firm resources for superior performance.

This theory provides the benefit to the firm specifically highlighting factors that create superior performance for a firm (Lockett, Thompson and Morgenstern, 2009). It allows executives of the organization to choose the most important strategic factors to invest in from a given range of probable strategic factors in any industry. Competencies are the firm's strengths that enable it to better differentiate its products or service quality by building technological system to respond to customers' needs, hence allowing the firm to compete more efficiently and successfully than other firms (Defillippi, 1990; Arend and Levesque, 2010).

For a firm to have competitive advantage and superior performance, resources and capabilities have to qualify as exceedingly valuable, rare, inimitable, and non-substitutable. The central premise of this research paper is that mutual coherence between IS priorities and initiatives and firm strategies is necessary to effectively prioritize IT activities and channel IS resources toward developing capabilities that are of strategic importance to the firm. Empirical studies have found that firms with a higher IS alignment are more likely to utilize IT for strategic purposes (Sabherwal, and King 1992) arrange IT resources and capabilities to support market positions (Henderson, and Venkatraman, 1993) and focus IT efforts on areas most critical to the firm to maintain and improve performance (Das, Zahra and Warkentin, 1991). This theory played a key role in evaluating and explaining IS capabilities of firms in Kenya's telecommunications industry that have the ability to create and maintain their competitive advantage. 


\section{1) Firm Performance}

Firm performance refers to organizational effectiveness in terms of its financial and operational performance (Venkatraman and Ramanujam, 1986). Financial performance has been the primary dependent variable employed in prior studies investigating the effects of IT capabilities on organisational performance. For example, Santhanam and Hartono (2003) investigated the direct effects of IT capabilities on firm performance. In their research, financial indicators, such as variations between the profit ratios and cost ratios were employed to operationalise firm performance. They reported that firms with superior IT capabilities exhibited superior current and sustained firm performance. In a similar study where performance was operationalised in terms of various profit and cost based performance measures, Bharadwaj (2000) reported that firms with high IT capability outperformed firms

Tallon, Kraemer and Gurbaxani (2000) perspective opens up many more avenues for research investigating the effects of IT capabilities on performance. Their perspective contrasts with prior research that focuses on improvements in financial performance at the organisational level. It also argues for a contingency-based approach towards selecting firm-level measures of performance when investigating the relationship between IT and firm performance. Specifically, Tallon et al. (2000) argued that financial performance measures can be appropriate when investigating firms that are operations focused; however, utilising the same measures to investigate firms that are market focused would be inappropriate.

Evan (1966) and Damanpour and Evan (1984) investigated the linkage between technological innovations and administrative innovations. They emphasise that firms introduce changes to their structures and processes in order to maintain or improve performance. While IS capabilities enable firms to improve financial performance and marketing performance, they also enable firms to achieve better control over their resources, enhance better coordination across a firm and allow firms to better plan for the future. Hence, IT investments also result in improved administrative performance. Based on the above arguments this research treats firm performance as a multidimensional construct consisting of three dimensions: financial performance, operational performance, and market based performance (market share). Financial performance refers to the variation between revenue and cost, higher revenue is an indication that a firm is performing financially. On the other hand operational performance refers to an organisational focus towards the efficiency in handling various business processes; improved control over its resources, enhanced co-ordination within organisations, and also the ability to foresee the future and prepare for changes while market share represents the percentage of an industry or market's total sales that is earned by a particular company over a specified time period.

\section{2) Information Systems Capabilities}

Capabilities are socially complex practices that determine the efficiency with which firms transform inputs into outputs (Collis, 1994). IS capabilities are the routines within the IS department that enable it to deliver IT services to the organization. The primary reason for this lies in the understanding that organisational capabilities are one of the major sources of competitive advantage and that capabilities are developed as a result of, or in the context of organisational resource allocations. This competitive advantage is sustained or diminished depending on the availability and allocation of resources that are rare and of better quality than others (Yashil, 2009).

While every company strives to be known for at least one of their capabilities, the external environment can play a role in moderating this impact. Other scholars have defined IS capabilities as an organisation's capacity to deploy resources in combinations that make appropriate business sense and provide the desired company results (Jarvenpaa and Leidner, 1998). Schreyogg and Kliesch-Eberl (2007) stipulate that capabilities can be built at various levels in the company such as at the departmental, divisional or organisational level.

Information systems' planning is an important process that enables organizations to identify business priorities and ensure that IS goals and initiatives are aligned with business priorities. It is likely that with sophisticated IS planning, a greater convergence between IS and business managers on IT priorities can be achieved (Boynton, Zmud, and Jacobs, 1994). Such convergence enables the synergistic integration of IT and business knowledge Boynton, et al. (1994), which in turn improves the identification and development of strategic IT applications (Reich and Benbasat, 1990).

In addition to making choices about targeting IT resources, firms have to successfully develop and implement technology solutions and ensure their effective utilization in order to improve their core competencies. Ability to develop high-quality 
applications in a timely and cost-effective manner is a critical capability that is likely to affect technology deployment (Rockart and Hoffman, 1992). A mature IS support process in addition can ensure that systems are effectively utilized by end users. Since firms cannot reap benefits from IT unless it is effectively used, IS support could determine how successful a firm is in using IT to improve its core competencies.

\section{3) Information Systems Capabilities and Firm Performance}

Akinbola et. al., (2014) in their research on market based capabilities and results; an inference for telecommunication service businesses in Nigeria, established that market capabilities has a large influence on organizational performance in its industry. Based on the findings, the study asserted that there is need for organizations to recognize their capabilities that will ensure organization performance.

Bhatt et al., (2014) in their empirical study on the types of Information Technology capabilities and their role in competitive advantage established that the importance of delineating capabilities such as relationship infrastructure that can facilitate differentiation in the marketplace, and dynamic capabilities such as organizational learning as an important antecedent to IT capability building. A study of managerial capabilities of Information Technology and firm performance, the role of eprocurement system by Oh S. et al., (2013) established that firms need to find a proper fit between their own information technology (IT) capabilities and IT systems in order to enhance performance.

Finally, a study to establish the Influence of organizational capabilities on the performance of sugar companies in Kenya by Nyangi, et al., (2015) found that there exists a statistically significant correlation between organizational capability and performance of sugar manufacturing firms. The empirical studies quoted indicate a difference majorly in context as compared with the current study. The present study intended to document knew knowledge by looking at IS capabilities influence on performance in the telecommunication industry in Kenya using a correlational and survey design with cross-sectional data collected using a structured questionnaire from executive, management and operational level managers from the four industry players namely Safaricom, Airtel, Telkom and Equitel which no other study cited has documented.

\section{Methodology}

This study employed both correlational and survey study research designs. Creswell (2012) defines correlation design as a statistical test to determine the tendency or pattern for two (or more) variables or two sets of data to vary consistently. In correlational research designs, researchers use the correlation statistical test to describe and measure the degree of association (or relationship) between two or more variables or sets of scores. This type of design was deemed useful in this study because apart from just describing, survey can also be used to explain and explore the existing status of two or more variables at a given point in time (Mugenda and Mugenda, 2003).

The researcher used survey design to obtain data form strategic, management and operational level managers of Safaricom, Airtel, Telkom and Equitel companies to help in describing, explaining and exploring the relationship between their information systems capabilities and performance. The population of interest comprised all the 408 executive, management, and operational level managers of the four telecommunications industry players in Kenya namely; Safaricom, Airtel, Telkom and Equitel from both business and IT departments.

Proportionate stratified sampling technique was employed to determine the sub-samples per company. Simple random Sampling was then applied to select the respondents from each stratum. Primary data on IS capabilities and firm performance was obtained using a structured fivepoint Likert scale questionnaire. Secondary data on measurement of IS capabilities and performance of the firms in the telecommunications industry in Kenya was obtained from literature published as peer reviewed work by researchers, books, periodicals and other related publication.

Data was analysed using both descriptive and inferential statistics. Qualitative data was also analysed using content analysis by summarizing and categorising the information gathered, coding it into different selected themes and presenting it in a narrative form. Multivariate regression analysis was used to determine the relationship between IS capabilities and performance.

\section{Findings}
4) Information Systems Capabilities and Firm Performance
The objective was to establish the influence of IS capabilities on firm performance.
Hypotheses Ho, stated, 
Ho: There is no significant relationship between IS capabilities and performance of firms in the telecommunications industry in Kenya.

Table 1: Model Summary for Regression Analysis for IS Capabilities and Performance

\begin{tabular}{|c|c|c|c|c|c|}
\hline Variable & $\begin{array}{l}\text { No. of } \\
\text { Observations }\end{array}$ & Beta & $\begin{array}{l}\text { Standard } \\
\text { Error }\end{array}$ & t- Statistic & p-value \\
\hline Constant & 202 & 14.223 & 1.377 & 10.325 & \\
\hline $\begin{array}{l}\text { IS Capabilities } \\
\mathbf{r}=.409 \\
\mathbf{r}^{2}=.167 \\
\mathbf{F}=40.205 \\
\text { Durbin Watson }=1.448\end{array}$ & 202 & .389 & .061 & 6.341 & .000 \\
\hline
\end{tabular}

$* \mathbf{p}<\mathbf{0 . 0 5}$

Source: Research Data, (2018)

The results in table 1 indicates the regression analysis of IS capabilities and firm performance. The correlation in the relationship between IS capabilities and firm performance is positive and significant $(\mathrm{r}=0.409, \mathrm{p}<0.05)$. This means that there was also a weak relationship between IS capabilities and firm performance indicating that whenever firms in telecommunications industry invested on market based IS capabilities there was a slight improvement on their performance.

The results of the regression indicated that IS capabilities significantly predicted firm performance $(\beta 1=.389, \mathrm{t}=6.341 ; \mathrm{p}<0.05)$, which means a unit increase in IS capabilities produced a 0.389 variation in firm performance. The $\mathrm{R}$ squared value indicated that IS capabilities explained 16.7 percent of the variance in performance $\left(r^{2}=0.167\right.$, $\mathrm{F}=40.205 ; \mathrm{p}<0.05)$. This demonstrates that the larger proportion of disparity in firm performance $(83.3 \%)$ is explained by other factors not captured in the second model. The Hypothesis that there is a significant relationship between IS capabilities and firm performance is therefore supported.

The results illustrates that better firm performance in the industry may not necessarily be attributable to IS capabilities in totality but could be based on how firms combine their IS resources and market based capabilities to enhance performance.

The findings are in line with Bharadwaj (2000) who posits that IS capabilities are derived from underlying strengths in IS human capital, IT infrastructure investment and IT-enabled intangibles such as IS partnership quality. The IT infrastructure offers the platform to launch innovative IT applications faster than the competition; the IS human capital resources enable firms to conceive and implement such applications faster than competition; and a focus on IT-enabled intangibles resources empowers firms to leverage or exploit pre-existing organizational intangibles such as vendor/customer orientation and synergy in the firm via co-presence.

The findings are also supported by Laudon and Laudon (2012) findings that IS capabilities play a key role in firm performance by enabling organizations to design innovative products and services, and to reduce the overall cost and time of developing the products and providing the services. These capabilities when used for production and operations can improve performance of companies that must plan, monitor, and control inventories, facilities, and the flow of products and services.

\section{Conclusions}

The study sought to find out the relationship between information systems capabilities and firm performance in telecommunications industry in Kenya. The hypothesis that there is no significant relationship between information systems capabilities and performance of firms in the telecommunications industry in Kenya was not accepted; and the study concluded that there was significant relationship between information systems capabilities and firm performance.

\section{Recommendations}

Based on the conclusion that there was significant relationship between information systems capabilities and firm performance, the study recommends that firms in the telecommunications industry in Kenya should invest in the development of market based information systems capabilities since they have significant influence on their performance.

\section{E. Limitations of the Study}

This research has achieved its aim of providing a general view on the influence of IS capabilities by 
exposing some of the significant associations between the context variables and firm performance in Kenya's telecommunications industry which may be indicative of a causal or non-causal effect of the said context. However some limitations were encountered these includes the following; the study interviewed only the management of the four companies under study who were well conversant with most of the study concepts; in some instances the researcher had to administer the questionnaire personally to them explaining the complex terms and concepts as related to the study variables. This was quite a tedious and demanding exercise; the study was also limited by lack of locally based studies in the topical area and hence may have led to inadequacy of the relevant empirical literature to regulate it.

Lastly, a longitudinal work to investigate the relationship of the three variables of IS capabilities and performance will provide more robust results than those of the snapshot research in the present study. However, the application of multiple research methods helped to avoid the potential biases in the research process. The limitations noted here do not however weaken the validity of the research undertaken and its findings.

\section{Suggestions for Future Research}

This study makes the following suggestions for future research: With respect to the methodology, a future longitudinal research based on specific case studies in the telecommunications industry could be undertaken. There should also be an analysis of other factors not captured in this study related to information systems capabilities and their relationship with firm performance. Lastly, another line of research could centre on the analysis of factors determining success in the identification and development of IS capabilities using this study's proposed model as the framework. However, it would be useful to include new factors related to IS resources and capabilities in future scales in order to analyse the extent to which the variance in performance can be explained by those new factors.

\section{References}

[1] Ainin, S., Akma, N., Salleh, M., Bahri, S., \& Faziharudean, T. M. (2015). Organization's Performance, Customer Value and the Functional Capabilities of Information Systems. Information Systems Management. 32(1), pp. 214.

[2] Akinbola, O.A., Adeniyi, A.O., \& Oluwatosin, O. B. (2014). Market Based Capabilities and Results: Inference for Telecommunication
Service Businesses in Nigeria. European Scientific Journal, 10(7), pp.1857-7881.

[3] Aldrich, H.E., \& Auster, E.R. (1986). Even Dwarfs Started Small: Liabilities of Age and Size and their Strategic Implications. In B.M. Staw and L.L. Cummings (eds.). Research in Organizational Behaviour (pp. 165-198). Greenwich, Connecticut: JAI Press.

[4] Antonia, M.G., \& Tomas, F.E. (2008). Strategic value and resources and capabilities of the information systems area and their impact on organizational performance in the hotel sector. Tourism Review, 63(3), pp. 21-47

[5] Arend, R.J., \& Levesque, M. (2010). Testing the Resource-Based View: Simulation Results for Violating VRIO. Organization Science, 21(4), pp. 913-930.

[6] Barney, J., Wright, M., \& Ketchen, D. J. (2001). The RBV of a firm; Ten years after 1991, Journal of management, 27(6), pp. 625-641.

[7] Barney, J. B. (2007). Gaining and Sustaining Competitive Advantage (3rd ed.). Upper Saddle River, NJ: Pearson Prentice Hall

[8] Bharadwaj, A.S. (2000). A resource-based perspective on information technology capability and firm performance: an empirical investigation. MIS Quarterly, 24(1), pp. 169196.

[9] Bhatt, G.D., \& Grover, V. (2005). Types of information technology capabilities and their role in competitive advantage: an empirical study. Journal of Management Information Systems, 22(2), pp. 253-77.

[10]Boynton, A.C., Zmud, R.W., \& Jacobs, G.C. (1994). The influence of IT management practice on IT use in large organizations. MIS Quarterly, 18(3), pp. 299-318.

[11]Brown, R.M., Gatian, A.W., \& Hicks, J.O. Jr (1995). Strategic information systems and financial performance. Journal of Management Information Systems, 11(4), pp. 215-48.

[12]Collis, D.J. (1994). Research note: How Valuable are Organizational Capabilities? Strategic Management Journal, 15(8), pp.143152.

[13]Creswell, J. W. (2012). Educational research: Planning, conducting, and evaluating quantitative and qualitative research (4th ed.). Boston, MA: Pearson.

[14]Damanpour, F., \& Evan, W. M. (1984). Organizational Innovation and Performance: The Problem of "Organizational Lag". Administrative Science Quarterly, 29(3), pp. 392-409. 
[15]Das, S.R., Zahra, S.A., \& Warkentin, M.E. (1991). Integrating the content and process of strategic MIS planning with competitive strategy. Decision Sciences, 22(1), pp. 953-984.

[16]Defillippi, R.J. (1990). Causal Ambiguity, Barriers to Imitation, and Sustainable Competitive Advantage. Academy of Management Review, 15(1), pp. 88-117.

[17]Evan, W. M. (1966). Organizational Lag. Human organization, 25(1), pp. 51-53.

[18]Fichman, R.G., \& Kemerer, C.F. (1993). Toward a theory of the adoption and diffusion of software process innovations. In L. Levine (ed.), Diffusion, Transfer and Implementation of Information Technology: Proceedings of IFIP TC8 Working Group Conference (pp. 23-31). New York, USA.

[19]Finney, R.Z., Lueg, J.E., \& Campbell, N.D. (2008). Market pioneers, late movers, and the resource-based view (RBV): A conceptual model. Journal of Business Research, 61(9), pp. 925-932.

[20]Hannan, M.T., \& Freeman, J. (1984. Structural inertia and organizational change. American Sociological Review, 49(1), pp. 149-164.

[21]Henderson, J.C., \& Venkatraman, N. (1993). Strategic alignment: Leveraging information technology for transforming organizations. IBM Systems Journal, 32(1), pp. 4-16.

[22]Jarvenpaa, S.L., \& Leidner, D. (1998). Information Company in Mexico: Extending the Resource-Based View of the Firm to a Developing Country Context. Information Systems Research, 9(4), pp.342-358.

[23]Kalyanaram, G., \& Wittink. D.R. (1994). Heterogeneity in entry effects between nondurable consumer product categories. International Journal of Research in Marketing, 11(3), pp. 219-231.

[24]Karimi, J., Somers, T.M., \& Bhattacherjee, A. (2007). The role of information systems resources in ERP capability building and business process outcomes. Journal of Management Information Systems, 24(2), pp. 60-221.

[25]Laudon, K. C., \& Laudon, J. P. (2012). Management information systems: Managing the digital firm. NJ: Prentice Hall.

[26]Lockett, A., Thompson, S., \& Morgenstern, U. (2009). The Development of the Resource-based View of the Firm: A Critical Appraisal. International Journal of Management Reviews, 11(1), pp.9-28.
[27]Mahoney, J. T., \& Pandian J. R. (1992). The resource-based view within the conversation of strategic management, Strategic Management Journal, 13(5), pp. 363-380.

[28]Makadok, R. (2001). Toward a synthesis of the resource-based and dynamic-capability view of rent creation. Strategic Management Journal, 22(5), pp. 387-401.

[29]Melville, N. Kraemer, K.L, \& Gurbaxani, V. (2004). Information Technology and Organisational Performance: An Integrative Model of IT Business Value. Management Information Systems Quarterly, 28(2), pp. 283322.

[30]Mitra, S., \& Chaya, A.K. (1996). Analyzing cost-effectiveness of organizations: the impact of information technology spending. Journal of Management Information Systems, 13(2), pp. 29-57.

[31]Mugenda, O.M \& Mugenda, A.G. (2003). Research methods: Qualitative and Quantitative

[32]Approaches. Nairobi: African centre for Technology Studies.

[33]Nyangi, O., Wanjere, M., Egessa, K., \& Wekesa M. (2015). Organizational Capabilities and Performance of Sugar Companies in Kenya. International Journal of Management Research \& Review, 5(8), pp. 845-863.

[34]Oh S., Yang H., \& Kim, S. W. (2013). Managerial Capabilities of Information Technology and Firm Performance: Role of eprocurement System Type. International Journal of Production Research, 4(2), pp. 44884506

[35]Rai, A., Patnayakuni, R., \& Seth, N. (2006). Firm performance impacts of digitally enabled supply chain integration capabilities. MIS Quarterly, 30(2), pp. 225-46.

[36]Ravichandran, T., \& Lertwongsatein, C. (2005). Effect of Information Systems Resources and Capabilities of Firm Performance: A ResourcedBased Perspective. Journal of Management Information Systems, 21(4), pp. 237-276.

[37]Ravichandran, T., \& Rai, A. (2000). Quality management in systems development: An organizational system perspective. MIS Quarterly, 24(3), pp. 381-416.

[38]Reich, B.H., \& Benbasat, I. (1990). An empirical investigation of factors influencing the success of customer-oriented strategic systems. Information Systems Research, 1(3), pp. 325-347. 
[39]Rockart, J.F., \& Hoffman, J.D. (1992). Systems delivery: Evolving new strategies. Sloan Management Review, 33(4), pp. 57-64.

[40]Sabherwal, R., \& King, W.R. (1992). Decisions processes for developing strategic applications of information systems. Decision Sciences, 23(4), pp. 917-943.

[41]Santhanam, R., \& Hartono, E. (2003). Issues in linking information technology capability to firm performance. MIS Quarterly, 27(1), pp. 125-65.

[42]Schreyogg, G., \& Kliesch-Eberl, M. (2007). How dynamic can organisational Capabilities be? Towards a dual-process model of capability dynamization. Strategic Management Journal, 28(9), pp. 913-933.

[43]Stinchcomb, A.L. (1965). Social structure and organizations. In J.G. March (ed.). Handbook of Organizations (pp. 142-193). Chicago: Rand McNally.

[44]Tallon, P. P., Kraemer, K. L., \& Gurbaxani, V. (2000). Executives' perceptions of the business value of information technology: a processoriented approach. Journal of Management Information Systems, 16(4), pp. 145-173.

[45]Teece, D.J., Pisano, G., \& Shuen, A. (1997). Dynamic capabilities and strategic management. Strategic Management Journal, 18(7), pp. 50933.

[46]Venkatraman, N., \& Ramanujam, V. (1986). Measurement of Business Performance in Strategy Research: A Comparison of Approaches. Academy of Management Review, 1(4), pp. 801-814.

[47]Wade, M., \& Hulland, J. (2004). The resourcebased view and information systems research: Review, extension, and suggestions for future research. MIS Quarterly, 28(1), pp. 107-142.

[48]Wernerfelt, B. (1984). A resource-based view of the firm. Strategic Management Journal, 5(2), pp. 71-80.

[49]Yashil, N. (2009). Effect of Information Systems Resources and Capabilities on Company Performance in the South African Financial Services Industry: A Resource Based Perspective. (Unpublished master's thesis), University of Pretoria, South Africa.

[50]Zhu, K., Kraemer, K.L., Xu, S., \& Dedrick, J. (2004). Information technology payoff in ebusiness environment: an international perspective on value creation of e-business in the financial services industry. Journal of Management Information Systems, 21(1), pp. 17-54. 